\title{
GAP ANALYSIS AND RISK OCCURENCE ON THE EXAMPLE OF PRESSURE TRANSMITTER'S PRODUCTION PROCESSES
}

\author{
Miloš Vorkapić1, Dragan Ćoćkalo², Vesna Spasojević Brkić3*, Dejan Đorđević1, Aleksandar Brkić4 \\ ${ }^{1}$ University of Belgrade, ICTM - CMT, Serbia \\ "University of Novi Sad, Technical faculty "Mihajlo Pupin" Zrenjanin, Serbia \\ ${ }^{3}$ University of Belgrade, Faculty of Mechanical Engineering, Serbia \\ ${ }^{4}$ Innovation Center, Faculty of Mechanical Engineering, Serbia
}

Gap analysis represents a tool for raising the level of performances of products, processes and enterprise organization which is rarely used in risk management. This paper proposes the joint application of Gap and Pareto analysis, in aim to mitigate possible risks in production processes. It is based on the facts that key points in the production process indicate some serious oversights (gaps), characterized as errors, which can grow into risky elements that disturb the manufacturing process and final transmitter assembly.

In this paper, finalizing and assembling pressure transmitter elements (modules), created by a domestic manufacturer, served as an example for the Gap analysis. Each electronic transmitter is consisted of three modules: measurement cell, mechanical coupling fixture and enclosure containing the electronics and the terminal block box. Through the implementation and assembly of these modules errors (or elements of potential risks) have been identified. Later on, using the Pareto chart, it has been seen that $80 \%$ of errors made during the transmitter manufacturing process have occured while implementing the first and the third transmitter module. Also, by analyzing the collected gaps, it has been concluded that the critical ones happen while using the existing technology and engaging workforce.

In order to eliminate the above-mentioned errors, this paper decidedly presents the Gap analysis steps which should be followed, so the transmitter manufacturing process would be improved in terms of quality. Similar methodology could be applied to other products and processes.

Key words: gap analysis, pareto chart, risk, manufacturing, processing, improvement, module, transmitter, quality

\section{INTRODUCTION}

By applying the Gap analysis and the Pareto chart, it is possible to collect certain data, mainly about the current status of enterprises, as well as about the possibilities to remove the irregularities and improve business activities and it is not usually applied on production processes. This paper will offer methodology to analyze the manufacturing process, as well as the process of assembling the final product using both Gap and Pareto analysis in aim to mitigate risks.

Researches in the field are not numerous. Using the example of process installation, Milazzo [1] approaches the error analysis (and their connections) methodically, through sensitivity and uncertainty, which indicates a high component failure rate with the following noted causes: human factor, equipment damaged before the exploitation, but also a more and more frequent usage of outdated technology. Also, Stanisavljev et al. [2] analyzed the occurence of the time gap when choosing the batch size in the manufacturing process. The idea of this paper is exactly to consider risks through the Gap analysis, as well as to realize all the steps needed for accepting or reducing their impact on the organization. It is exactly from this setting that one can ascertain that the risk includes resources, process activities, relations, defined plans, as well as final responsibilities within the organization. Risk, by definition, represents a certain level of probability (or uncertainty) regarding the desired outcome [3]. Risks are multidimensional and that is why they need to be separated, so the causes, outcomes and trends are clearly determined. Also, technical risks occuring within design and technology, will be analyzed [4]. This type of risks, by its nature, should be carefully estimated when making decisions in the project [5-6]. According to the same sources, consideration of technical risks improves the processes in accordance with described procedures and reduces costs of faulty products (repairs, warranties and additional services). In this regard, Stamenković et al. [7] were considering the product warranty as one of the risk factors which includes additional costs for manufacturers. In the early phase of developing and planning the product technology, a lot of errors have occurred. If these errors are not discovered and removed in this phase, there will be a progressive increase of the general costs regarding quality of the product. Also, unforeseen changes and errors occur during planning. By researching and analyzing, Tilley et al. [8] identified a series of risky factors concerning design and documentation, like for example: 1) issues with inadequate design, 2) non-existing design check, 3) issues with deadlines, 4) inadequate and inexperienced design team, 5) short time for quick market demands (tenders). According to Kliem [9], more and more attention today is being paid to technical risks, which means: 1) inability to determine the relationships between key processes; 2) lack of access to technical 
expertise; 3) lack of agreement about designing analysis, tools and techniques; 4) lack of knowledge about the application of technology; 5) choosing the wrong technology and 6) limits in applying existing IT technology. In addition to this, Williams [10] points out that failures of large engineering projects are leading to severe damages which can occur due to not considering the risks. That is why Miller and Lessard [4] stated that understanding and managing risks represents a challenging task for designers in the early phase. Some of the risks can be mitigated or decreased by teamwork, while with some risks each designer has to cope individually [11].

\section{METHODOLOGY}

\section{Gap analysis}

Gap analysis represents a tool for raising the level of product, process and enterprise performance. It helps enterprises determine where they wish to be and find the gap between that place and a place where they are positioned now [12]. Vukelić et al. [13] designed a methodology of locating the gap during the production process based on a scheme for timely selection of correct elements (pieces).

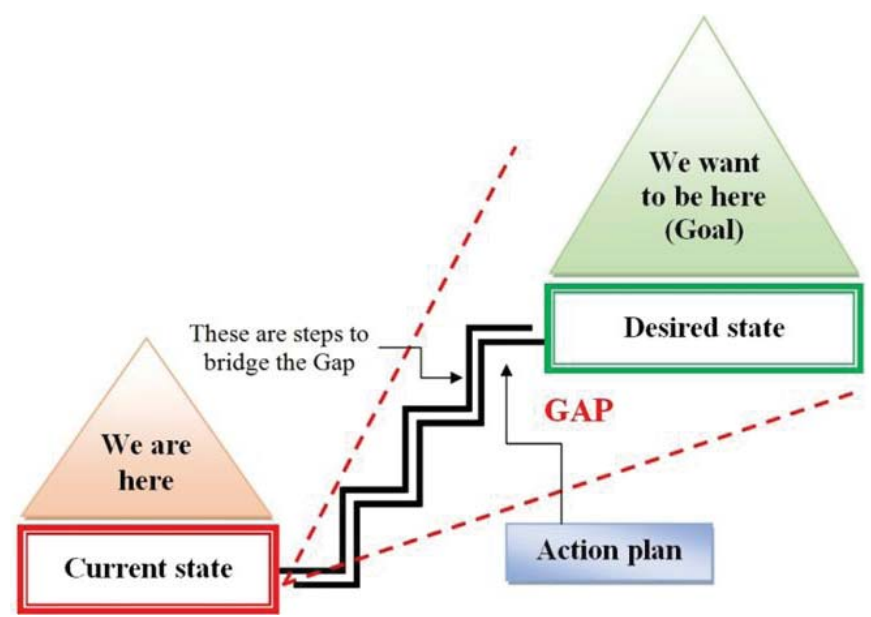

Figure 1: Schematic representation of the Gap analysis

In the Figure 1, there is a path which bridges the gap (or a potential risk). That is how an action plan is made, outlining the exact actions that must be taken to finally eliminate the gap.

According to Davis et al. [14], Tsai et al. [15], Marra et al. [16], the Gap analysis process consists of 5 steps:

1. Describing the area of activity - This step describes the area of activity which is supposed to be analyzed and improved. Firstly, the range of motion and the analysis must be defined. However, given that the entire area of activity is being described, those activities can be various - wide and focusing on the entire business, but also narrower and focused on a particular business process, depending on the defined company goals (see Table 1). The analysis of these areas can be quantitative and qualitative. In this regard, the Gap analysis report should contain a column named „future status”, which indicates company's defined and desired goals, as well as the current status.

2. Identifying specific areas for improvement - Here, specific areas for improvement are identified, regarding the areas of activity given in the step 1 .

3. Setting goals - When the areas of activity suitable for improving are identified, the next step is to set goals for each area. These goals should be realistic, which means they ought to be achievable in the defined time limit, but also synchronized with the company's business goals.

4. Determining the current status - The present status of the company should be determined, before embarking on a realistic action plan making. This step is to realize if the company is improving towards the desired status in achieving the goal defined beforehand. Also, this is a time to gather as many information as possible, in order to clarify the current status. The gap we talked about is created somewhere between this and the previous step.

5. Establishing steps of action or bridging the gap Here, the steps for the improvement are being described, i.e. the action plan is being defined, in order to reach the desired status. One way to write an action plan is to determine the most critical gaps, that is, to recognize what prevents the enterprise to achieve its goals - to define risky spots. In this step, all possible solutions that could be implemented should be listed, in order to bridge the gap between present and future views.

During the product realization, a certain number of errors occurs and those are all sources of potential risks. This number is mostly generated in the production process. In the Table 2, a report layout is given, describing the current status and guidelines for the future status.

Gap analysis can be useful for analyzing the process approach which should include: lowering costs and shortening the duration of activities, more efficient use of resources, consistent and predictable results, as well as focusing on the improvement possibilities [17].

When it comes to the checklist, it can be said that it represents a starting point for identifying potential risky places. Existence of one or more potential risks (or risky places) can lead to catastrophic consequences because of the omissions in procedures and activities meant to fix those errors. These risks have the biggest impact on productivity, performances, quality and economy of the production process. In Table 3, there is an example of the checklist.

In case it is stated that the risky event (gap) (1) is present, it implies that the description of the event (2) should include the information about what the risk (gap) represents and the contributing factors (3). In the column (4), clear and objective reasons are being listed, together with the specific terms. 
Table 1: Steps in the Gap Analysis Process

\begin{tabular}{|l|l|l|}
\hline Entrance & Activities & Exit \\
\hline Area of activity & $\begin{array}{l}\text { Analyzing the area, starting from the broader } \\
\text { context and then narrowing it down. }\end{array}$ & $\begin{array}{l}\text { Submitting the report describing the current } \\
\text { status and recommendations about the future. }\end{array}$ \\
\hline $\begin{array}{l}\text { Identification } \\
\text { of specific } \\
\text { places }\end{array}$ & $\begin{array}{l}\text { Identifying specific places (or potential risky } \\
\text { spots) to be improved. }\end{array}$ & $\begin{array}{l}\text { Making lists of specific places where errors } \\
\text { and potential risks can occur; Creating a } \\
\text { checklis; Offering improvement measures. }\end{array}$ \\
\hline Goals & $\begin{array}{l}\text { After defining specific places, goals for removing } \\
\text { errors or potential risks are determined in the } \\
\text { defined time line. }\end{array}$ & $\begin{array}{l}\text { Providing a list of goals and deadlines for } \\
\text { debugging, according to the defined specific } \\
\text { place. }\end{array}$ \\
\hline Current state & $\begin{array}{l}\text { Discovering areas with weaker performances, } \\
\text { compared to competitors. }\end{array}$ & $\begin{array}{l}\text { Giving recommendations for improving pro- } \\
\text { cesses, products or organizations. }\end{array}$ \\
\hline $\begin{array}{l}\text { Bridging the } \\
\text { gap }\end{array}$ & $\begin{array}{l}\text { Writing down the steps for the improvement, as } \\
\text { well as their order. }\end{array}$ & $\begin{array}{l}\text { Creating an action plan containing all possible } \\
\text { solutions for decreasing the gap (risk). }\end{array}$ \\
\hline
\end{tabular}

Table 2: Layout of current and future status reports

\begin{tabular}{|l|l|l|l|}
\hline \multicolumn{2}{|l|}{ Department: } & \multicolumn{1}{c|}{$\begin{array}{l}\text { Gaps } \\
\text { (or potential } \\
\text { risks) }\end{array}$} & $\begin{array}{l}\text { Required } \\
\text { efforts to } \\
\text { solve } \\
\text { or bridge } \\
\text { the gaps }\end{array}$ \\
\hline \multicolumn{2}{|l|}{ Present situation } & Operation & Activity \\
& & $\begin{array}{l}\text { Future } \\
\text { situation }\end{array}$ \\
\hline
\end{tabular}

Table 3: Checklist in Gap Analysis

\begin{tabular}{|c|c|c|c|c|}
\hline No. & $\begin{array}{c}\text { Risky } \\
\text { event } \\
(1)\end{array}$ & $\begin{array}{c}\text { Description } \\
(2)\end{array}$ & $\begin{array}{c}\text { Conditional } \\
\text { variables } \\
(3)\end{array}$ & $\begin{array}{c}\text { Note } \\
(4)\end{array}$ \\
\hline & & & & \\
\hline
\end{tabular}

In the column (3) of conditional variables (measurable parameters), the parameters reaching critical value can be determined, as well as how much they are falling into the risk zone. According to Garza-Reyes et al. [18], risk occurrence can be illustrated by using different colors and those are:

- $\quad$ Green - Little impact or no risk;

- $\quad$ Yellow - Low or moderate risk;

- $\quad$ Red - High impact and risk; and

- $\quad$ Grey - Risk unknown or incomplete.

Pareto chart would be useful precisely for collecting errors, deviations and defects. Using this chart will help in finding places where gaps occur, recorded errors, as well as the repetition rate.

The action plan within the Gap analysis includes describing the area of activity and the steps necessary to bridge the gap (see Table 4). Within the action plan, all the necessary activities should be defined, in order to ensure a complete harmony between process elements [16]. The plan should include: (1) process, (2) process step, (3) current results, (4) desired results, (5) action, (6) target date.
According to Cheng and Musaphir [19], a large number of managers are worried about the application of product strategy. The reason is the implementation of the action plan into product strategy, which includes measurement performances, decision making and management styles.

Table 4: Action Plan in Gap Analysis

\begin{tabular}{|c|c|c|c|c|c|c|}
\hline \multirow{2}{*}{ No. } & Process & $\begin{array}{c}\text { Process } \\
\text { step }\end{array}$ & $\begin{array}{c}\text { Current } \\
\text { results }\end{array}$ & $\begin{array}{c}\text { Desired } \\
\text { results }\end{array}$ & Action & $\begin{array}{c}\text { Target } \\
\text { date }\end{array}$ \\
\cline { 2 - 7 } & $(1)$ & $(2)$ & $(3)$ & $(4)$ & $(5)$ & $(6)$ \\
\hline & & & & & & \\
\hline
\end{tabular}

\section{Pareto chart}

Pareto chart is used for analyzing the issues that are being broken down to smaller pieces. It enables achieving the highest possible improvements by using all the available resources within the company. Pareto principle states that a small number of samples causes the most issues. According to Haron and Kairudin [20], Pareto hypotesis „80-20" is about an experiential fact saying that $80 \%$ of errors (issues) is caused by $20 \%$ of factors (causes). In practice, this ratio is $75-25,70-30$ etc. Govindaluri and Cho [21] view Pareto as a decision-maker optimization model, i.e. the most suitable design solution is being chosen, while minimizing deviations (or potential risks).

Pareto chart is used for identifying the relative significance of certain data related to details of the process that is being monitored. This quality chart is suitable for cases in which it is possible to identify errors, their frequency and/or the follow-up expenses, as well as to undertake corrective activities as a function of error elimination [22].

\section{CASE STUDY}

In this paper, implementing and assemblying the pressure transmitter by the domestic manufacturer IHTMCMT will serve as an example. The period of tracking and collecting errors during manufacturing and assemblying the transmitter lasted from January 2015 to September 2017 , when errors (or potential risks) were grouped according to modules. 


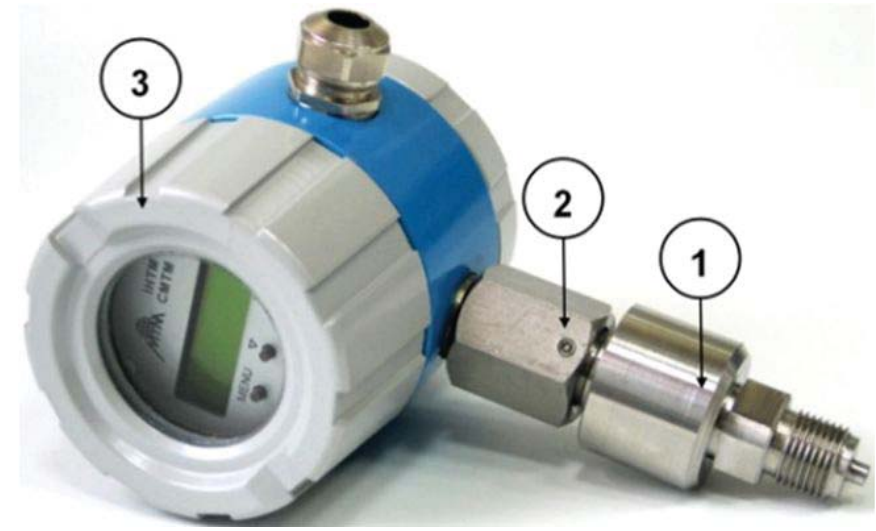

Figure 2: Realized pressure transmitter through modules:

1) measurement cell (containing the sensing element);

2) mechanical coupling fixture; 3) enclosure, containing the electronics and the terminal block box

Each electronic transmitter is consisted of three modules: 1.) measurement cell (containing the sensing element), 2.) mechanical coupling fixture and 3.) enclosure, containing the electronics and the terminal block box. In the Figure 2, there is a photographic appearance of the realized transmitter through modules.

According to Gershenson et al. [23], it is necessary that all the product modules are detachable and designed for repeated use and recycling. In the Table 5, there is a summary of number of components and necessary technological operations in the implementation of the transmitter module.

Many production systems require complex manufacturing and assembly operations which are later being integrated in the final product [24]. That is why it is important to consider the system modularity through defining a plan, proper distribution of activities (operations) and managing, in order to design product (or a process) [25]. In general, modular product design has several advantages: ease of assembly and maintenance [26], as well as simple adaptability of architecture to new changes [27].
This paper deals with the gap analysis in a complex design of the product manufacturing and assembling process. By introducing the Pareto-optimizing chart, the modularity of the product and the distribution of structural components at the module level are discussed. It is very important to understand the essence of the structural complexity of the product (or the process).

Complexity occurs with products consisted of many components, which can be connected in a wrong way [28]. Products with more components represent a complex structure in the sense of designing, developing and connecting [29].

\section{EXPERIMENTAL WORK}

Gap analysis has been carried out on the example of the electronic pressure transmitter. It is stated that certain irregularities exist and that a gap in the manufacturing and assemblying process of the transmitter occured. For that reason, solving of the encountered issues started, through five steps of the Gap analysis. The first step, related to the area of activity, is closely focused on the manufacturing department. As an exit solution, the report on the current and future situation is given in the Table 6.

The second step, indicating specific areas for improvement, is defined in the step 1. Actually, the manufacturing process department is being considered (wider concept), more precisely, connecting parts and components, as well as final control of products (narrower concepts). The third step offers a perception of the future status, i.e. defines future company goals for overcoming gaps.

The fourth step is very important and crucial for further analysis. Current irregularities, errors, deficiencies and deviations from target values are being discovered. In this regard, in order to detect irregularities in the manufacturing process, the Pareto chart was used, which later served as a base for making a diagram. In the Table 7, errors and their frequency in recording the situation are classified and presented.

Table 5: Summary of required elements and technological operations in the implementation of the transmitter module

\begin{tabular}{|c|l|c|l|}
\hline No. & Module name & $\begin{array}{l}\text { Number of } \\
\text { components }\end{array}$ & Technological operations \\
\hline 1. & $\begin{array}{l}\text { Measurement } \\
\text { cell }\end{array}$ & 6 & $\begin{array}{l}\text { Element processing according to technical and technological documentation } \\
\text { Vacuuming and filling the cell with oil } \\
\text { Welding cell elements } \\
\text { Soldering electronic components }\end{array}$ \\
\hline 2. & $\begin{array}{l}\text { Mechanical } \\
\text { coupling fixture }\end{array}$ & 2 & Element processing according to technical and technological documentation \\
\hline 3. & $\begin{array}{l}\text { Enclosure, } \\
\text { containing the } \\
\text { electronics } \\
\text { and the termi- } \\
\text { nal block box }\end{array}$ & 9 & $\begin{array}{l}\text { Element processing according to technical and technological documentation } \\
\text { Using external technologies } \\
\text { Implementing the electronic circuit }\end{array}$ \\
\hline
\end{tabular}


Table 6: The report on the current and future situtation of the transmitter

\begin{tabular}{|c|c|c|c|c|}
\hline \multicolumn{3}{|c|}{ Department: Transmitter production } & \multirow{2}{*}{ Gaps or potential risks } & \multirow{2}{*}{$\begin{array}{c}\text { The required efforts to solve } \\
\text { or bridge the gaps }\end{array}$} \\
\hline No. & Operation & Activity & & \\
\hline \multicolumn{4}{|c|}{ Present situation } & Future situation \\
\hline \multicolumn{5}{|c|}{ I-Sensor element assembly } \\
\hline 1 & $\begin{array}{c}\text { Cell } \\
\text { production }\end{array}$ & $\begin{array}{l}\text { Electro-resistant } \\
\text { cell welding }\end{array}$ & $\begin{array}{l}\text { Implementation problems during cell } \\
\text { vacuuming or encapsulating. The problem } \\
\text { is in the technological obsolescence of the } \\
\text { apparatus for electro-resistant welding. }\end{array}$ & $\begin{array}{l}\text { Ensure the apparatus } \\
\text { functionality. }\end{array}$ \\
\hline 2 & $\begin{array}{c}\text { Oil } \\
\text { filling }\end{array}$ & $\begin{array}{l}\text { Machine } \\
\text { preparation }\end{array}$ & $\begin{array}{l}\text { Poor machine preparation and } \\
\text { element finishing. }\end{array}$ & $\begin{array}{l}\text { Improve the final control of } \\
\text { element processing. }\end{array}$ \\
\hline 3 & $\begin{array}{l}\text { Welded } \\
\text { joint }\end{array}$ & $\begin{array}{l}\text { Plasma } \\
\text { welding }\end{array}$ & $\begin{array}{l}\text { Quality of the welded joint depends also on } \\
\text { the machine preparation of element being } \\
\text { welded and the } \\
\text { welding parameters. }\end{array}$ & $\begin{array}{l}\text { Check the prepared } \\
\text { surfaces and welding } \\
\text { parameters according to the } \\
\text { prescribed technology. }\end{array}$ \\
\hline 4 & $\begin{array}{l}\text { Membrane } \\
\text { piercing }\end{array}$ & $\begin{array}{l}\text { Welded joint } \\
\text { testing }\end{array}$ & $\begin{array}{l}\text { Inadequate choice of welding } \\
\text { parameters can lead to the } \\
\text { combustion of the circular metal } \\
\text { membrane. }\end{array}$ & $\begin{array}{l}\text { Perform continuous } \\
\text { inspection of the welded } \\
\text { joint - visually and via } \\
\text { helium detectors. }\end{array}$ \\
\hline \multicolumn{5}{|c|}{ II - Mechanical coupling fixture and Measurement cell } \\
\hline 1 & $\begin{array}{l}\text { Element } \\
\text { production }\end{array}$ & $\begin{array}{l}\text { Machine element } \\
\text { production }\end{array}$ & $\begin{array}{l}\text { Impact of malfunctioning processing } \\
\text { machines can lead to poor manufacturing } \\
\text { quality of final pieces. The machines are } \\
\text { technologically, economically and timely } \\
\text { outdated, and servicing and parameter } \\
\text { control is not regular. }\end{array}$ & $\begin{array}{l}\text { Improve final control of } \\
\text { element processing. } \\
\text { Provide funds for purchasing } \\
\text { new processing machines } \\
\text { or new generation repaired } \\
\text { machines. }\end{array}$ \\
\hline 2 & $\begin{array}{l}\text { Element } \\
\text { assembly }\end{array}$ & $\begin{array}{l}\text { Merging and } \\
\text { control }\end{array}$ & $\begin{array}{l}\text { Errors occur in the coupling of the cell (with } \\
\text { wire leads) and other mechanical parts of } \\
\text { the measurement cell. }\end{array}$ & $\begin{array}{l}\text { Improve final control during } \\
\text { element coupling. }\end{array}$ \\
\hline 3 & $\begin{array}{l}\text { Welded } \\
\text { joint }\end{array}$ & $\begin{array}{l}\text { Welded joint } \\
\text { testing }\end{array}$ & $\begin{array}{l}\text { Welded joint depends on the machine } \\
\text { processing of elements, as well as on } \\
\text { choosing the welding parameter. }\end{array}$ & $\begin{array}{l}\text { Perform continuous } \\
\text { inspection of the welded } \\
\text { joint - visually and via } \\
\text { helium detectors. }\end{array}$ \\
\hline 4 & $\begin{array}{l}\text { Transition } \\
\text { piece }\end{array}$ & $\begin{array}{l}\text { Machine element } \\
\text { production }\end{array}$ & $\begin{array}{l}\text { It connects the measurement cell with the } \\
\text { transmitter electronics box. Errors occur at } \\
\text { the machine worksop level. }\end{array}$ & $\begin{array}{l}\text { Improve final control during } \\
\text { element coupling. }\end{array}$ \\
\hline \multicolumn{5}{|c|}{ III - Electronics box } \\
\hline 1 & $\begin{array}{l}\text { Box and } \\
\text { electronics }\end{array}$ & $\begin{array}{c}\text { Merging and } \\
\text { controlling } \\
\text { electrical compo- } \\
\text { nents }\end{array}$ & $\begin{array}{l}\text { On the box, errors occur at the machine } \\
\text { workshop level. For electronic circuits, } \\
\text { errors occur when coupling and soldering } \\
\text { components on printed boards, as well as } \\
\text { during the assembly. }\end{array}$ & $\begin{array}{l}\text { Improve final control of } \\
\text { machine element processing } \\
\text { and electronic component } \\
\text { coupling. }\end{array}$ \\
\hline 2 & $\begin{array}{l}\text { Box enod- } \\
\text { izing }\end{array}$ & $\begin{array}{c}\text { Other party } \\
\text { technology (or } \\
\text { service) } \\
\end{array}$ & $\begin{array}{l}\text { Surface protection technology. (This } \\
\text { procedure is a service activity - other party } \\
\text { technology is being used). }\end{array}$ & $\begin{array}{l}\text { Provide better (visual) } \\
\text { control of received elements. }\end{array}$ \\
\hline 3 & $\begin{array}{l}\text { Element } \\
\text { assembly }\end{array}$ & Final control & $\begin{array}{l}\text { Errors occur due to careless assembly and } \\
\text { verification of metrological parameters of } \\
\text { the final product. }\end{array}$ & $\begin{array}{l}\text { Provide additional staff } \\
\text { training. Carry out a process } \\
\text { of receiving and control of } \\
\text { parameters, as well as } \\
\text { storing the final product. }\end{array}$ \\
\hline
\end{tabular}


Table 7: Errors in the manufacturing process and the transmitter assembling modules

\begin{tabular}{|c|c|c|}
\hline \multicolumn{3}{|c|}{ I - Assembling sensor element } \\
\hline Op. & Name & Frequency \\
\hline 1. & Cell production & 7 \\
\hline 2. & Oil filling & 3 \\
\hline 3. & Welded joint & 4 \\
\hline 4. & Membrane piercing & 11 \\
\hline \multicolumn{3}{|c|}{$\begin{array}{l}\text { II - Mechanical coupling fixture + } \\
\text { Measurement cell }\end{array}$} \\
\hline 1. & Element production & 44 \\
\hline 2. & Element assembly & 4 \\
\hline 3. & Welded joint & 9 \\
\hline 4. & Transition piece & 6 \\
\hline \multicolumn{3}{|c|}{$\begin{array}{l}\text { III - Enclosure, containing the } \\
\text { electronics and the terminal block box }\end{array}$} \\
\hline 1. & Box and electronics & 22 \\
\hline 2. & Box enodizing & 3 \\
\hline 3. & Element assembly & 5 \\
\hline
\end{tabular}

The highest frequency in the first module occurred during the membrane piercing (11) and the cell production quality (7); in the second module during element production (44), while the highest frequency in the third module happened during production of the welded joint of measurement cell elements (9), as well as production of the box and electronics (22).
Table 8: Pareto error analysis in the production process of transmitter modules

\begin{tabular}{|c|l|c|c|c|}
\hline No. & Error source & Frequency & $\begin{array}{c}\text { Relative } \\
\text { frequency } \\
(\%)\end{array}$ & $\begin{array}{c}\text { Cum. } \\
\text { relative } \\
\text { frequency } \\
(\%)\end{array}$ \\
\hline II-1 & $\begin{array}{l}\text { Element } \\
\text { production }\end{array}$ & 44 & 47,31 & 47,31 \\
\hline III-1 & $\begin{array}{l}\text { Box and } \\
\text { electronics }\end{array}$ & 22 & 23,66 & 70,97 \\
\hline I-4 & $\begin{array}{l}\text { Metal } \\
\text { membrane } \\
\text { piercing }\end{array}$ & 11 & 11,83 & 82,80 \\
\hline II-3 & $\begin{array}{l}\text { Welded joint } \\
\text { of the } \\
\text { measurement } \\
\text { cell }\end{array}$ & 9 & 9,68 & 92,48 \\
\hline I-1 & $\begin{array}{l}\text { Cell } \\
\text { production } \\
\text { quality }\end{array}$ & 7 & 7,52 & 100,00 \\
\hline
\end{tabular}

In this regard, data about relative and cum. relative frequencies is given in the Table 8, while the Pareto chart, shown in the Diagram 1, is based on this data.

By modifying the Table 8 and based on registered frequencies, factors are listed in descending order, starting from those with the highest occurence frequency to those with the lowest one. Based on the Pareto chart, it is obvious that $70.97 \%$ of errors (or risky operations) during the transmitter manufacturing process, occur in the implemetation of the third module - box and electronics.

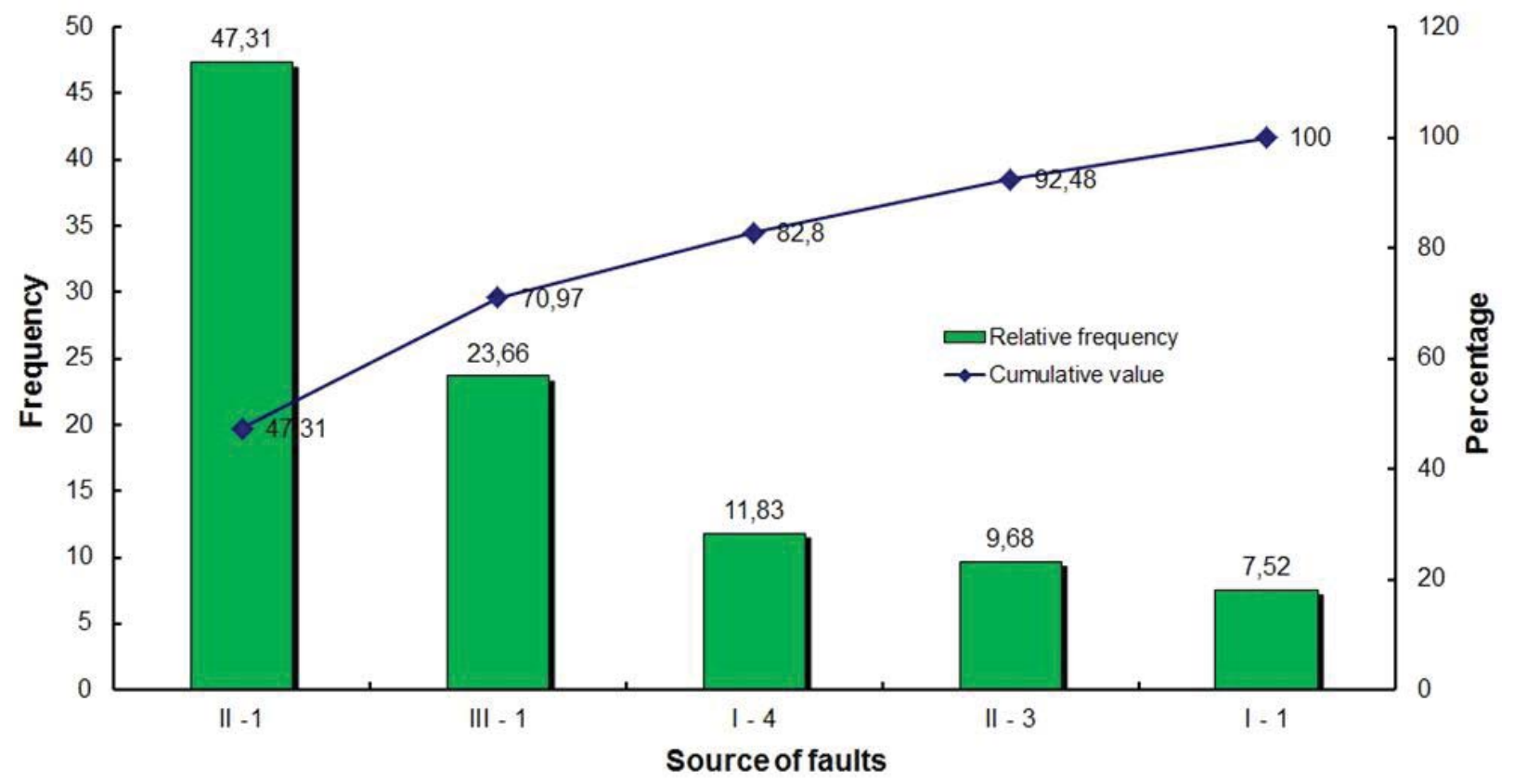

Diagram 1: Pareto diagram of the production process transmitters 
After the Pareto analysis of discovering weaknesses of the transmitter implementation, a control chart is created, as a starting point for identifying potential risky places, according to the highest level of frequency. In the Table 9, there is a control chart display.
In the last step of the Gap analysis, an action plan for the implementation of possible solutions is made, in order to remove oversights between present and future status. In the Table 10, there is an action plan for the transmitter module manufacturing and assembling process.

Table 9: Checklist in the manufacturing and assembly process of transmitter modules

\begin{tabular}{|l|l|l|c|l|}
\hline S/N & \multicolumn{1}{|c|}{$\begin{array}{c}\text { Risky event } \\
(1)\end{array}$} & $\begin{array}{l}\text { Risky event description } \\
(2)\end{array}$ & $\begin{array}{c}\text { Conditional } \\
\text { variables } \\
(3)\end{array}$ & \multicolumn{1}{|c|}{$\begin{array}{c}\text { Note } \\
(4)\end{array}$} \\
\hline I-1 & Cell production & $\begin{array}{l}\text { Electro-resistant cell } \\
\text { welding }\end{array}$ & 7 & $\begin{array}{l}\text { Maintaining } \\
\text { Control }\end{array}$ \\
\hline I-4 & Membrane piercing & Welded joint testing & 11 & Control \\
\hline II-1 & Element production & $\begin{array}{l}\text { Machine element } \\
\text { production }\end{array}$ & 44 & Control \\
\hline II-3 & Welded joint & Welded joint testing & 9 & $\begin{array}{l}\text { Merge } \\
\text { Control }\end{array}$ \\
\hline III-1 & Box and electronics & $\begin{array}{l}\text { Merging and controlling } \\
\text { electrical components }\end{array}$ & 22 & $\begin{array}{l}\text { Processing } \\
\text { Control }\end{array}$ \\
\hline
\end{tabular}

Table 10: Action Plan in the manufacturing and assembly process of transmitter modules

\begin{tabular}{|c|c|c|c|c|c|c|}
\hline No. & Process & Process step & $\begin{array}{l}\text { Current } \\
\text { results }\end{array}$ & $\begin{array}{l}\text { Desired } \\
\text { results }\end{array}$ & Action & Target date \\
\hline & (1) & (2) & (4) & (5) & (6) & $(7)$ \\
\hline 1 & $\begin{array}{c}\text { Cell } \\
\text { production }\end{array}$ & $\begin{array}{l}\text { Electro- } \\
\text { resistant cell } \\
\text { welding }\end{array}$ & $\begin{array}{c}\text { Improve } \\
\text { maintenance } \\
\text { and control }\end{array}$ & $\begin{array}{c}\text { Remove } \\
\text { irregularities }\end{array}$ & Staff training & Up to 2 weeks \\
\hline 2 & Oil filling & $\begin{array}{c}\text { Machine } \\
\text { preparation }\end{array}$ & $\begin{array}{l}\text { Improve } \\
\text { processing }\end{array}$ & $\begin{array}{c}\text { Remove } \\
\text { irregularities }\end{array}$ & $\begin{array}{c}\text { Review } \\
\text { processing } \\
\text { technology }\end{array}$ & Up to one month \\
\hline 3 & Joint welding & $\begin{array}{l}\text { Plasma } \\
\text { welding }\end{array}$ & Improve control & $\begin{array}{c}\text { Remove } \\
\text { irregularities }\end{array}$ & Staff training & Up to 2 weeks \\
\hline 4 & $\begin{array}{l}\text { Membrane } \\
\text { piercing }\end{array}$ & $\begin{array}{l}\text { Welded joint } \\
\text { testing }\end{array}$ & Improve control & $\begin{array}{c}\text { Remove } \\
\text { irregularities }\end{array}$ & Staff training & One week \\
\hline 5 & $\begin{array}{l}\text { Element } \\
\text { production }\end{array}$ & $\begin{array}{l}\text { Machine } \\
\text { element } \\
\text { production }\end{array}$ & Improve control & $\begin{array}{c}\text { Remove } \\
\text { irregularities }\end{array}$ & $\begin{array}{c}\text { Review } \\
\text { processing } \\
\text { technology }\end{array}$ & Up to 2 weeks \\
\hline 6 & $\begin{array}{l}\text { Element } \\
\text { assembly }\end{array}$ & $\begin{array}{l}\text { Merging and } \\
\text { control }\end{array}$ & Improve control & $\begin{array}{c}\text { Remove } \\
\text { irregularities }\end{array}$ & Staff training & One week \\
\hline 7 & Welded joint & $\begin{array}{l}\text { Welded joint } \\
\text { testing }\end{array}$ & $\begin{array}{c}\text { Improve } \\
\text { merging and } \\
\text { control }\end{array}$ & $\begin{array}{c}\text { Remove } \\
\text { irregularities }\end{array}$ & $\begin{array}{c}\text { Review } \\
\text { processing } \\
\text { technology }\end{array}$ & Up to 2 weeks \\
\hline 8 & Transition piece & $\begin{array}{l}\text { Machine } \\
\text { element } \\
\text { production }\end{array}$ & Improve control & $\begin{array}{c}\text { Remove } \\
\text { irregularities }\end{array}$ & $\begin{array}{c}\text { Review existing } \\
\text { technology }\end{array}$ & One week \\
\hline 9 & $\begin{array}{l}\text { Box and } \\
\text { electronics }\end{array}$ & $\begin{array}{l}\text { Merging and } \\
\text { controlling } \\
\text { electrical } \\
\text { components }\end{array}$ & $\begin{array}{c}\text { Improve } \\
\text { processing and } \\
\text { control }\end{array}$ & $\begin{array}{c}\text { Remove } \\
\text { irregularities }\end{array}$ & $\begin{array}{c}\text { Review } \\
\text { processing } \\
\text { technology } \\
+ \\
\text { Staff training }\end{array}$ & Up to one month \\
\hline 10 & Box enodizing & $\begin{array}{c}\text { Other party } \\
\text { technology (or } \\
\text { service) }\end{array}$ & Improve control & $\begin{array}{c}\text { Remove } \\
\text { irregularities }\end{array}$ & Staff training & One week \\
\hline 11 & $\begin{array}{c}\text { Element } \\
\text { assembling }\end{array}$ & Final control & Improve control & $\begin{array}{c}\text { Remove } \\
\text { irregularities }\end{array}$ & Staff training & One week \\
\hline
\end{tabular}




\section{DISCUSSION}

After finishing the Gap analysis and according to the report and action plan that has been carried out, it can be concluded that the main causes of the gap (or risky element) occurrence are the following:

1. Outdated processing technology. Here we talk about the machines which are technically outdated and not calibrated. That leads to bigger complications in the sense of respecting tolerances defined by technical documentation. From this point of view, it represents a technical risk because outdated technology is still being used [30], but also someone else's technology as well.

2. Human factor. When it comes to the human factor, issues are multidimensional and the ones with the biggest impact are: poor control in the work place, poor training and staff incompetency for the expected position.

All indicators show that these two gap factors must be systematically removed, so the production process can continue undisturbed.

\section{CONCLUSION}

Thanks to Gap analysis and Pareto chart, some key points in the production process have been marked as they indicate major oversights characterized as errors. However, their repeatability means that they turn into risky operations which are disturbing the production process and final transmitter assembly. Gap analysis offers important steps in removing the gap. Gaps represent the base for error occurence and so the number and frequency of their occurrence must be taken into account. If these errors remain unremoved, potential risks can appear. Gap analysis helps the organization notice potential risk factors which lead to deviations of the quality from planned values, as well as to process interruptions. Also, negative effects can be minimized and improvement possibilities used fully.

According to the Pareto chart, it is concluded that almost $80 \%$ of errors (or risky elements) during the transmitter production process occur in the implementation of the first and the third module, as they are consisted of all the gaps characteristic for technology and people.

Therefore, more attention should be paid during finalizing processes of producing machine parts (assemblies and subassemblies), as well as electric circuits. It means that, by eliminating those errors in the production process, oversights (risks) would be lowered for over $70 \%$, which would be important for improving the level of quality and faster transmitter implementation.

\section{ACKNOWLEDGEMENT}

This work is a part of current projects TR-32008 and TR-35017 funded by Ministry of Education, Science and Technological Development of the Republic of Serbia.

\section{REFERENCES}

1. Milazzo, M. F. [2016]. O značaju menadžerskih i organizacionih varijabli u kvantitativnoj proceni rizika. Journal of Applied Engineering Science, 14(1), 5460.

2. Stanisavljev, S., Ćoćkalo, D., Đorđević, D., Minovski, R. [2013]. The production cycle time in serial production: Reduction of the duration in metal processing industry case. Journal of Applied Engineering Science, 11(3), 15-122.

3. Conrow, E.H., \& Shishido, P.S. (1997). Implementing risk management on software intensive projects. IEEE Software, 14(3), 83-89. doi:10.1109/52.589242

4. Miller, R., \& Lessard, D. (2001). Understanding and managing risks in large engineering projects. International Journal of Project Management, 19(8), 437443. doi:10.1016/s0263-7863(01)00045-x

5. Michalska, J. (2006). Quality costs in the production process. Journal of Achievements in Materials and Manufacturing Engineering, vol. 17, no. 1-2, 425428.

6. Sousa, S., Nunes, E., \& Lopes, I. (2015). Measuring and managing operational risk in industrial processes. FME Transaction, 43(4), 295-302. doi:10.5937/ fmet1504295s

7. Stamenković, D., Popović, V., Spasojević-Brkić, V., \& Radivojević, J. [2011]. Model optimizacije kombinacije garancije besplatne zamene i parcijalne garancije. Journal of Applied Engineering Science, 9(4), 457-464.

8. Tilley, P.A., Mcfallen, S.L., \& Tucker, S.N. (2000). Design and Documentation Quality and Its Impact on the Construction Process. AISC - IEAust Special Issue Steel Construction, vol. 34, no. 4, 7-14.

9. Kliem, R.L. (2000). Risk Management for Business Process Reengineering Projects. Information Systems Management, 17(4), 66-68. doi:10.1201/1078 /43193.17.4.20000901/31256.12

10. Williams, T. (1995). A classified bibliography of recent research relating to project risk management. European Journal of Operational Research, 85(1), 18-38. doi:10.1016/0377-2217(93)e0363-3

11. Polk, R., Plank, R.E., \& Reid, D.A. (1996). Technical risk and new product success: An empirical test in high technology business markets. Industrial Marketing Management, 25(6), 531-543. doi:10.1016/ s0019-8501(96)00071-5

12. Awasthi, M. K., Sarsaiya, S., Wang, Q., Wang, M., Chen, H., Ren, X., Kumar, S., \& Zhang, Z. (2018). Mitigation of Global Warming Potential for Cleaner Composting, Biosynthetic Technology and Environmental Challenges, Springer, Singapore, p. 271305., DOI: 10.1007/978-981-10-7434-9_16 
13. Vukelić, Đ., Budak, I., Tadić, B., Lužanin, O., Hadžistević, M., \& Krizan, P. [2011]. Automatizovano generisanje šema baziranja radnog predmeta prilikom projektovanja pribora. Journal of Applied Engineering Science, 9(3), 383-392.

14. Davis, R., Misra, S., \& Van Auken, S. (2002). A gap analysis approach to marketing curriculum assessment: A study of skills and knowledge. Journal of Marketing Education, vol. 24, no. 3, 218-224, DOI: $10.1177 / 0273475302238044$

15. Tsai, W. H., Hsu, W., \& Chou, W. C. (2011). A gap analysis model for improving airport service quality. Total Quality Management \& Business Excellence, vol. 22, no. 10, 1025-1040, DOI: 10.1080/14783363.2011.611326

16. Marra, M., Di Biccari, C., Lazoi, M., \& Corallo, A. (2018). A Gap Analysis Methodology for Product Lifecycle Management Assessment. IEEE Transactions on Engineering Management, vol. 65, no. 1, 155-167, DOI: 10.1109/TEM.2017.2762401

17. Mogos, M. F., Fredriksson, A., \& Alfnes, E. (2019). A production transfer procedure based on risk management principles. Journal of Global Operations and Strategic Sourcing, vol. 12, no. 1, 103-150, DOI: 10.1108/JGOSS-01-2018-0001

18. Garza-Reyes, J.A., Romero, J. T., Govindan, K., Cherrafi, A., \& Ramanathan, U. (2018). A PDCA-based approach to Environmental Value Stream Mapping (E-VSM). Journal of Cleaner Production, vol. 180, 335-348, DOI: 10.1016/j.jclepro.2018.01.121

19. Cheng, T. C. E., \& Musaphir, H. (1996). Theory and practice of manufacturing strategy. International Journal of Production Research, vol. 34, no. 5, 12431259, DOI: 10.1080/00207549608904963

20. Haron, N. Z., \& Kairudin, F. L. M. (2012). The application of quality function deployment (QFD) in the design phase of industrialized building system (IBS) apartment construction project. European International Journal of Science and Technology, vol. 1, no. 3, 56-66

21. Govindaluri, S. M., \& Cho, B. R. (2007). Robust design modeling with correlated quality characteristics using a multicriteria decision framework. The International Journal of Advanced Manufacturing Technology, vol. 32, no. 5, 423-433, DOI: 10.1007/ s00170-005-0349-6
22. Sokovic, M., Pavletic, D., \& Fakin, S. (2005). Application of Six Sigma methodology for process design. Journal of Materials Processing Technology, vol. 162, 777-783, DOI: 10.1016/j.jmatprotec.2005.02.231

23. Gershenson, J. K., Prasad, G. J., \& Zhang, Y. (2004). Product modularity: measures and design methods. Journal of engineering Design, vol. 15, no. 1, 33-51, DOI: $10.1080 / 0954482032000101731$

24. EIMaraghy, W., ElMaraghy, H., Tomiyama, T., \& Monostori, L. (2012). Complexity in engineering design and manufacturing. CIRP Annals-Manufacturing Technology, vol. 61, no 2, 793-814, DOI: 10.1016/j. cirp.2012.05.001

25. Baldwin, C. Y., \& Clark, K. B. (2000). Design rules: The power of modularity. MIT press.DOI: 10.7551/ mitpress/2366.001.0001

26. Hölttä-Otto, K., \& De Weck, O. (2007). Degree of modularity in engineering systems and products with technical and business constraints. Concurrent Engineering, vol. 15, no. 2, 113-126, DOI: 10.1177/1063293X07078931

27. Engel, A., Browning, T. R., \& Reich, Y. (2017). Designing products for adaptability: insights from four industrial cases. Decision Sciences, vol. 48, no. 5, 875-917, DOI: 10.1111/deci.12254

28. Sinha, K. \& Suh, E. S. (2018). Pareto-optimization of complex system architecture for structural complexity and modularity. Research in Engineering Design, vol. 29, no. 1, 123-141, DOI: 10.1007/s00163-0170260-9

29. Rechtin, E. \& Maier, M. W. (2010). The art of systems architecting. CRC press.

30. Branscomb, L. M. \& Auerswald, P. E. (2003). Taking Technical Risks: How Innovators, Managers, and Investors Manage Risk in High-Tech Innovations. MIT Press.

Paper submitted: 02.09.2019.

Paper accepted: 26.11.2019. This is an open access article distributed under the CC $B Y-N C-N D 4.0$ terms and conditions. 